Association for Information Systems

AIS Electronic Library (AISeL)

AMCIS 2004 Proceedings

Americas Conference on Information Systems

(AMCIS)

December 2004

\title{
Marketing Strategies through Customer Attention: beyond technology-enabled customer relationship management
}

Raymond Hackney

Manchester Metropolitan University

Ashok Ranchhod

Southampton Business School

Marilyn Hackney

Manchester Metropolitan University

Follow this and additional works at: http://aisel.aisnet.org/amcis2004

\section{Recommended Citation}

Hackney, Raymond; Ranchhod, Ashok; and Hackney, Marilyn, "Marketing Strategies through Customer Attention: beyond technology-enabled customer relationship management" (2004). AMCIS 2004 Proceedings. 7.

http://aisel.aisnet.org/amcis2004/7

This material is brought to you by the Americas Conference on Information Systems (AMCIS) at AIS Electronic Library (AISeL). It has been accepted for inclusion in AMCIS 2004 Proceedings by an authorized administrator of AIS Electronic Library (AISeL). For more information, please contact elibrary@aisnet.org. 


\title{
Marketing Strategies through Customer Attention: beyond technology-enabled customer relationship management
}

\author{
Ray Hackney \\ Manchester Metropolitan University, UK \\ r.hackney@mmu.ac.uk
}

\author{
Ashok Ranchhod \\ Southampton Business School, UK \\ ranchhod@btinternet.com
}

\author{
Marilyn Hackney \\ Manchester Metropolitan University, UK \\ m.hackney@mmu.ac.uk
}

\begin{abstract}
This paper presents a conceptual analysis of utilising aspects of contemporary psychological theories to develop marketing practice. It attempts to extend our understanding of identified approaches which frequently fail to recognise the subtle complexities associated with customer attention. This is perceived to be a critical factor in marketing strategies where instances of organisational objectives, consumer behaviours and individual preferences are systematically investigated. The intention is to augment well established concepts from technology-enabled customer relationship management (CRM) towards an initial and exploratory framework, designed to explore the nature of attention as applied to consumer agendas. Further research is suggested, through both theoretical constructs and empirical analysis, which is argued to represent, so called, A-commerce (attention). It is believed that these approaches will provide for more valuable insights into future successful marketing directions.
\end{abstract}

\section{Keywords}

psychology, marketing, customer relationship management, attention

\section{INTRODUCTION}

There is an abundance of evidence that traditional approaches to organisational marketing, subsequently related to the added value through eBusiness strategies, is more dependent upon inspiration than information (Ranchhod \& Hackney, 1997). There is also a long tradition towards developing evolutionary marketing methodologies where the opportunity to enable a learning culture through human experience and a continuous process of innovation is not apparent (Hackney et al, 2004). The challenge for contemporary commercial transacting is increasingly related to tribal marketing identified through both supply and demand side factors. Many organisations have recognised the importance of maintaining on-line value constellations (Hackney \& Burn, 2001) where they form emerging virtual communities to exploit the advantages of internet capabilities, as shown in Fig 1. 


\section{On-line Value Constellations}

\begin{tabular}{|c|c|c|}
\hline Business Model & Features & Examples \\
\hline $\begin{array}{l}\text { Virtual Face } \\
\text { (e-shop) }\end{array}$ & $\begin{array}{l}\text { place to space } \\
\text { for products through } \\
\text { a single enterprise }\end{array}$ & $\begin{array}{l}\text { * Harris } \\
\text { Technology } \\
\text { * Boots } \\
\text { On-line }\end{array}$ \\
\hline Virtual Alliance & $\begin{array}{l}\text { sharing of business } \\
\text { resources URL, represents } \\
\text { the common interface enables } \\
\text { cross-reference of participating } \\
\text { sites }\end{array}$ & $\begin{array}{l}\text { * SCB Co-op } \\
* \text { Jane Books } \\
* \text { LAA } \\
* \text { Green Grocer }\end{array}$ \\
\hline Virtual Community & $\begin{array}{l}\text { electronic market space } \\
\text { involving a number of } \\
\text { organisations and on-line } \\
\text { business models }\end{array}$ & $\begin{array}{l}* \text { Best of Italy } \\
* \text { Sofcom }\end{array}$ \\
\hline
\end{tabular}

Figure 1: On-line Value Constellations (Hackney \& Burn (2001)

These supply side features (Fig 1) for virtual transacting have progressed the exploitation of technology quite well. New ways of organising have certainly enabled more efficient processing of customer data and provided additional value to the marketing function. However, there is an obvious lack of focus in these systems which ignore the ways customers recognise and perceive the products and services offered, i.e. demand side factors. This paper attempts to redress this imbalance through a proposed extension of current analysis for customer relationship management.

\section{BEYOND CUSTOMER RELATIONSHIP MANAGEMENT}

Ongoing research within customer relationship management (CRM) goes some way to address contemporary marketing issues (Berry, 1995). Studies frequently demonstrate the obvious importance of building long term partnerships through product and service consistency, interaction, intelligence and customisation. The essential objective is clearly to engage in producing a value added customer portfolio. Most critically there is a recognised urgency to make the transition from a product to a customer focus. These are identified through considerations from production technologies which allow mass customisation, developing product category management systems, concentrations on service provision and devising key account teams to manage customer expectations and needs (Homburg et al, 2000). This has led to a movement towards customer-centric marketing which seeks to address uncertainties inherent in complex markets and devise approaches to satisfice promotion challenges. Clearly, marketing approaches are now essentially dynamic and location attributes from place to space are becoming increasingly apparent (Sheth et al, 2000). The new on-line environment is prevalent in presenting customers with choices and control over this marketing mix (Kitchen,1999) 
More recently interest has also emerged in concepts associated with U-Commerce where the opportunities from wireless web technologies (Watson et al, 2003). There are numerous practical examples of these technologies which facilitate rapid and novel communication, i.e. paying bills over a mobile telephone and even one, most recently, using GPRS (general packet radio switched) technology which functions from the wrist (Samsung, 2003). Consequently, U-commerce (ultimate) extends the facilities available through E-commerce (electronic) and M-commerce (mobile) towards a fully integrated system of communication access and transaction processing, as shown in Figure 2.

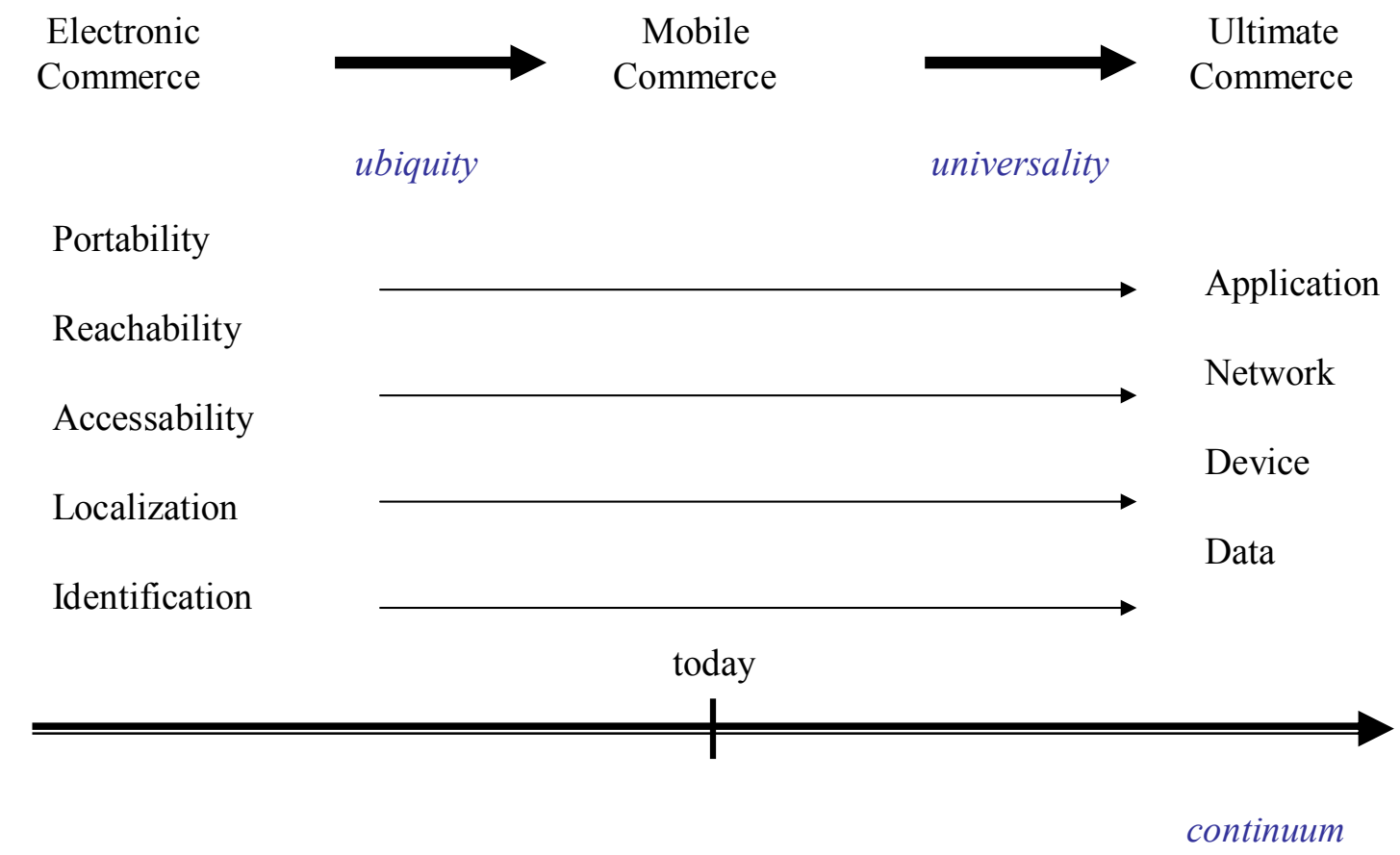

Figure 2: Compilation of E-commerce Transition (Watson et al, 2003)

However, as noted, these systems are impotent to the challenges of customer behaviour where technology alone will not provide for the perceived value proposition in commercial activities. Investments in technology forms an enabling factor but not a guarantee of customer capitulation to products and services available within complex and competitive markets. It is useful to note that early theories of IS have consistently demonstrate that technology in isolation is an inadequate indicator of organisational performance enhancement (Lyytinen \& Yoo, 2003) - we need to extend this argument to individual customer preferences and attempt an analysis of their attention behaviour.

\section{THE NATURE OF CUSTOMER ATTENTION}

Restak (2004) argues that, 'The era of the Old Brain has given way to that of the New Brain'. He notes earlier medical research where very limited perspectives of neural patterns were possible due to the inaccessibility of existing surgical techniques. However, contemporary facilities, enabled through imaging technologies, now record subtle and fascinating activities that could not be examined previously. We have entered the realm of cognitive science where analysts can study human mechanisms responsible for thoughts, moods, decisions and actions. More specifically, Restak (2004) 
notes that we are now able to understand more fully the effects of media and technology on our thoughts and emotions. There is substantive evidence that our brains increasingly respond to television, mobile phones, laptops and the Internet. For example, crawlers of text at the bottom of television screens are designed to attract our attention but their prevalence now has decreasing impact. Such information overload is also well documented where decision agents are incorporated within web sites to enable comparison shopping (Tan, 2003). Again, this assumes that the consumer is currently and actively engaged in the commercial process.

It is critical to gain customer attention prior to and additional to the noted technology-driven marketing strategies. Clearly, if the consumer is unaware of available products and services then any approach for securing their business is significantly reduced. It is argued therefore that gaining customer attention is equally, or indeed, more important than a rational long term focus upon traditional customer relationship management. What is required is a strategic focus on the real complexity of the relationship which organisations are initially able to establish with customers. Indeed, it also augments the blunt instrument of branding and advertising where passive and indifferent customer behaviour is frequently evident. The core of individual activity is driven by identified motivations and recognised goals, which are based on the perceived relevance of the product and service offered.

It is cautionary to note at this stage that aspects of advertising and branding are argued to be insufficient to capture the real dimensions of consumer behaviour. There is, of course, a proliferation of techniques, often subliminal to audience perceptions, related to ambient advertising where the message is strategically positioned in an attempt to maximise customer awareness. The success of these approaches is regarded to be varied and limited given the huge amount of available sources to the customer (Tan, 2003). Similarly, the notion and implementation of branding, particularly on the internet, results in a significantly diluted message given the extent of the information communicated. Consequently, efforts are frequently made to attain loyalty from consumers and again evidence leads us to believe that this provides limited success (Mazur, 2000). A perspective emerges in this respect that most approaches through advertising and indeed clever branding are highly passive in their impacts. We need to be more specific, adaptive and proactive to the dynamics of commerce, which, as noted, may usefully be attempted at attracting the conscious level of customer behaviour. The nature and extent of gaining customer attention is central to this fundamental objective (Davenport \& Beck, 2001).

Consider, for example, the concepts articulated through Goode's Chart as illustrated in Figure 3. 


\section{FRONT OF MIND}

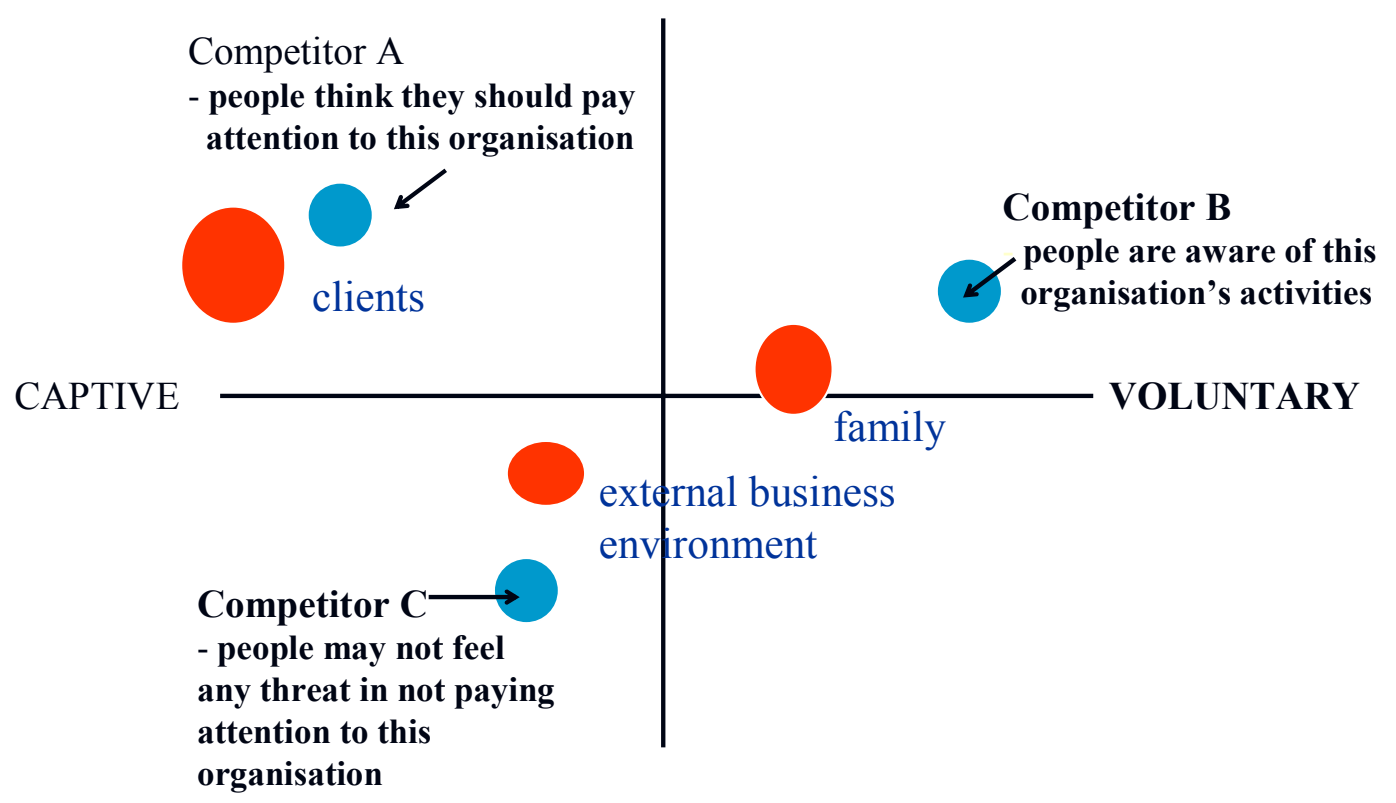

BACK OF MIND

Figure 3: The Nature of Customer Attention (Davenport and Back, 2001)

Figure 3 (Goode's Chart) presents a conceptual view of perhaps how organisations may be mapped according to their visibility to customers. This is potentially a critical aspect of customer relationship management given the diversity and uncertainly associated with global markets. For example, the basis of this approach is to identify the position of (say?) the family. In this instance close relatives are readily positioned as front of mind and voluntary. This is self -explanatory where we are not forced to consider this relationship and our families are always at the forefront of our thinking and therefore attention. This may be extended to consider (say?) one of our business clients. Here the relationship is slightly different where a client is not a close family member and therefore some additional effort is required to formulate attention towards them. In this case clients are still front of mind, due to their importance as business associates, but we have to work at capturing, i.e. focussing our attention towards them. The value of Goode's chart therefore is to consider the mechanisms for ensuring that an organisation is indeed at the front of a potential customer's mind. This requires far more than a formal methodology and prescriptive systems design. The ideal is to replicate the activities of Competitor A who have been able to capture customer attention that would result in added value to their markets.

\section{FUTURE RESEARCH AGENDA}


The core objective is to engage customer attention to realise product or service value which results in improved business performance (Timmers, 1999; Amit \& Zott, 2001). These notions have been analysed through Social Presence Theory where the extent of E-business communication is its ability to enable a superior level of interaction with customers (Rice \& Love, 1987). What is required is a personal connection to facilitate demand side awareness factors of a particular organisation. This is an area where the use of different media effects how customers view, think and relate to their perceived relationship within the business and represents a critical issue relative to the nature and extent of the customer interface. The essential features of this, so called, A-commerce (attention) would be to capture this awareness, as noted in Figure 4;

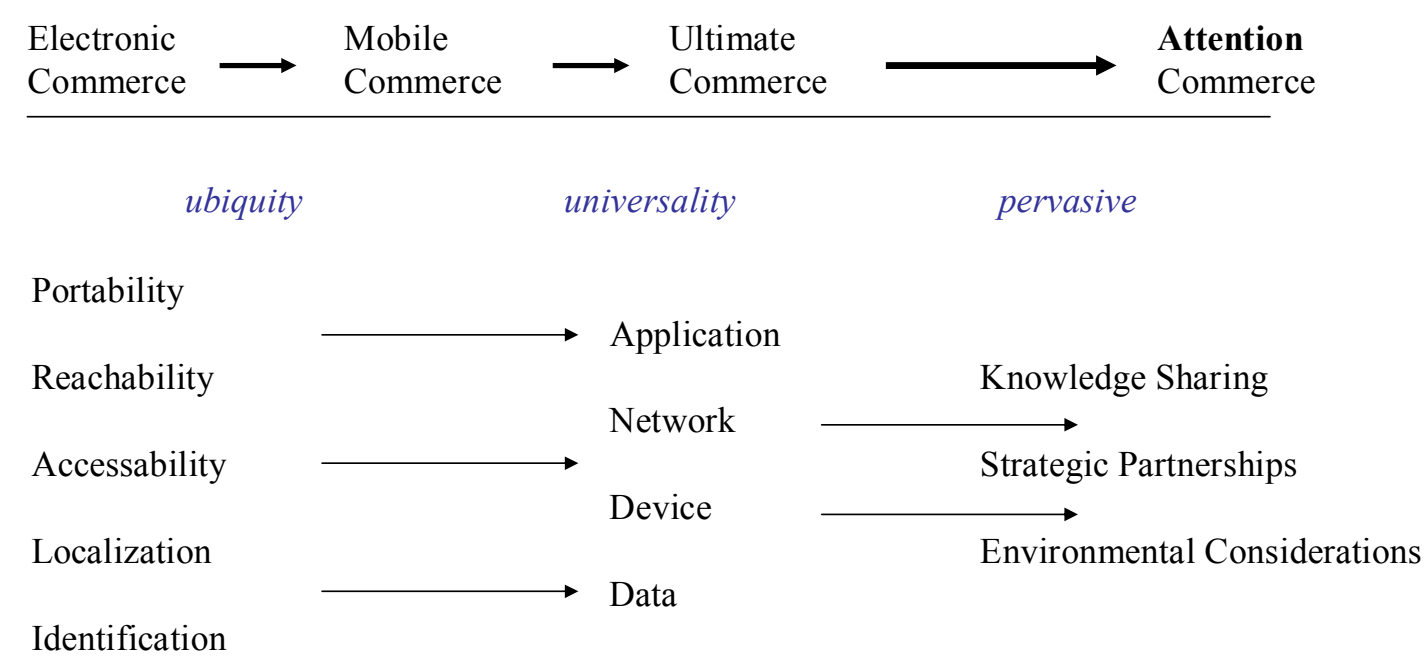

supply side factors

demand side factors

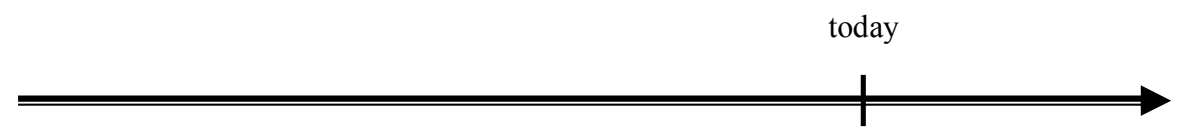

continuum

Figure 4: Towards A-commerce and Demand Side CRM

Organisations need to form effective partnerships with customers, to develop elite front line staff, to engage customers in their strategic intentions, provide timely and adequate feedback, to relate to environmental considerations and to engage in pervasive knowledge sharing. These activities clearly challenge current notions for customer relationship management.

It is conceivable, for example, that marketers will need to utilise psychological concepts and develop models through social marketing which are more realistic to these demand-side factors (Currie, 2003). The bold utopia of the exploitation of internet technologies requires more imaginative approaches which extend beyond our current fascination and investment in technology alone. Attention allows us to select from a myriad of external factors, to engage in mental processing, to link with our consciousness and to base our decisions on (product/service) relevance (Eysenck \& Keane, 1999). Within contemporary marketing strategies these factors require critical analysis. 
Empirical research therefore should focus upon concepts associated with A-commerce and interpreted through qualitative methodologies in an attempt to surface the rich complexities of customer attention. This is encouraged through adopting longitudinal analysis that would enable investigators to understand these factors evolving over time. Customer attention has usually been attained through disruptive advertising on television, billboards, bold banners and pop-ups on the internet. However, with new technologies and the ubiquity of their reach we should recognise the softer underlying issues, e.g., emotions, trust, reciprocity, awareness, etc. The opportunity for more adaptive theories (psychology, etc), as applied to marketing, should also be considered in an attempt to provide useful insights into the nebulous phenomena associated with customer attention - the challenge is clearly how to operationalise these constructs.

\section{CONCLUSION}

It is beyond the scope of this paper to outline little more than a brief overview of the proposed research agenda but it is felt that more critical thinking is required to overcome the static, contextual and technology-based approaches to marketing which are currently prevalent (Tedlow, 1993; Ranchhod, 2004).

More effort is required to exploit those avenues of research where we can understand the new currency of eBusiness. This requires more imaginative thinking for systems design, technology exploitation and customer receptivity (Fig 4). The essence of this approach is to formulate a deeper recognition of what drives customer motivations to engage in certain attention behaviour. A central theme is to develop mechanisms, through eBusiness electronic media, which focuses their attention on the product or service offered. Clearly, this is more inspirational than normally provided by systems designers but increasingly essential in exploiting highly competitive markets.

\section{REFERENCES}

1. Amit R \& Zott C (2001) Value Creation in eBusiness, Strategic Management Journal, 22, pp 493-530

2. Berry, L (1995) Relationship Marketing of Services: growing interest, emerging perspectives, Journal of the Academy of Marketing Science, 23(4) pp 236-245

3. Currie W (2003) Value Creation from Application Services Provisioning: lessons from four vendor firms, ICIS2003 Proceedings (Seattle, USA), December

4. Davenport T H \& Beck J C (2001) The Attention Economy, Harvard Business School Press, USA

5. Eysenck M W \& Keane, M C (1999) Cognitive Psychology, Psychology Press, UK

6. Hackney R A \& Burn J (2001) SPECS - Strategic Planning for E-Commerce Systems: towards a e-customer focus, International Journal of E-Business Strategic Management, Vol 2, No 4, pp 281-291

7. Hackney R A, Burn J \& Salazar A (2004) Strategies for Value Creation in eMarkets: towards a framework for managing evolutionary change, Journal Strategic Information Systems (forthcoming June, 2004) 
8. Homburg C H, Workman J P \& Jensen O (2000) Fundamental Changes in Marketing Organization: the movement towards a customer-focused organizational structure, Journal of the Academy of Marketing Science, 28(4), pp 459-478

9. Kitchen P J (1999) Marketing Communications: principles and practice, Thompson Business Press, London

10. Lyytinen K \& Yoo Y (2003) The Next Wave of Nomadic Computing: a research agenda for information systems research, Information Systems Research, (13)4, pp 377-388

11. Mazur L (2000) Internet Spin-Offs Show Crisis within Traditional Brands, Marketing, 23 March, pp 20-21

12. Sheth J N , Sisodia R S \& Sharma A (2000) The Antecedents and Consequences of CustomerCentric Marketing, Journal of the Academy of Marketing Science, 29(1), pp 55-66

13. Ranchhod A (2004) Marketing Strategies: a twenty first century approach, Prentice Hall

14. Ranchhod A \& Hackney R A (1997) 'Marketing through Information Technology: from potential to reality, Academy of Marketing, 1, pp 779-786

15. Restak R (2004) The New Brain: how the modern age is rewiring your mind', Rodale Publishing (UK)

16. Rice \& Love (1987) Electronic Emotion: socioemotional content in a computer mediated network, Communication Research, 14(1), pp 85-108

17. Samsung (2003) www.samsung.com

18. Tan C-H (2003) Comparison-Shopping Websites: an empirical investigation of the influence of decision aids and information load on consumer decision-making behaviour, ICIS2003 Proceedings (Seattle, USA), December

19. Timmers P (1999) Business Models for Electronic Commerce, John Wiley \& Sons, Chichester, UK

20. Watson R T, Pitt L F, Berthon P \& Zinkhan G M (2002) U-Commerce: extending the universe of marketing, Journal of the Academy of Marketing Science 30(4), pp 329-343

21. Tedlow R S \& Jones G (1993)(eds) The Rise and Fall of Marketing, London, Routledge 